\title{
Low CD4/CD8 ratio predicts cancer risk among adults with HIV
}

Jessica L. Castilho, M.D., M.P.H. ${ }^{1}$; Aihua Bian, M.P.H. ${ }^{2}$; Cathy A. Jenkins, M.S. ${ }^{2}$; Bryan, E. Shepherd, Ph.D. ${ }^{2}$; Keith Sigel, M.D. ${ }^{3}$; M. John Gill, M.D. ${ }^{4}$; Mari M. Kitahata, M.D., M.P.H. Michael J. Silverberg, Ph.D., M.P.H. ${ }^{6}$; Angel M. Mayor, M.D. ${ }^{7}$; Sally B. Coburn, M.P.H. ${ }^{8}$; Dorothy Wiley, Ph.D., R.N. ${ }^{9}$; Chad J. Achenbach, M.D. ${ }^{10}$; Vincent C. Marconi, M.D. ${ }^{11}$; Ronald J. Bosch, Ph.D. ${ }^{12}$; Michael A. Horberg, M.D. ${ }^{13}$; Charles Rabkin, M.D. ${ }^{14}$; Sonia Napravnik, Ph.D. ${ }^{15}$; Richard M. Novak, M.D. ${ }^{16}$; W. Christopher Mathews, M.D., M.S.P.H. ${ }^{17}$; Jennifer E. Thorne, M.D., Ph.D. ${ }^{18,8}$; Jing Sun, M.D., M.P.H., Ph.D. ${ }^{8}$; Keri N. Althoff, Ph.D., M.P.H. ${ }^{8}$; Richard D. Moore, M.D., M.H.S. ${ }^{19}$; Timothy R. Sterling, M.D. ${ }^{1}$; and Staci L. Sudenga, Ph.D. ${ }^{20}$ for the North American AIDS Cohort Collaboration on Research and Design (NA-ACCORD) of the International Epidemiology Databases to Evaluate AIDS (IeDEA)

Affiliations:

1. Division of Infectious Diseases, Department of Medicine, Vanderbilt University Medical Center, Nashville, TN, USA

2. Department of Biostatistics, Vanderbilt University Medical Center, Nashville, TN, USA

3. Division of Infectious Diseases, Department of Medicine, Mount Sinai School of Medicine, New York, NY, USA

4. Department of Medicine, University of Calgary, Calgary, AB, Canada

5. Division of Allergy \& Infectious Diseases, Department of Medicine, University of Washington, Seattle, WA, USA

6. Division of Research, Kaiser Permanente Northern California, Oakland, CA, USA

7. Retrovirus Research Center, Internal Medicine Department, Universidad Central del Caribe School of Medicine, Bayamón, PR, USA

8. Department of Epidemiology, Johns Hopkins Bloomberg School of Public Health, Baltimore, MD, USA

9. School of Nursing, University of California Los Angeles, Los Angeles, CA, USA

10. Division of Infectious Diseases, Department of Medicine, Northwestern Feinberg School of Medicine, Chicago, IL, USA

11. Division of Infectious Diseases, Emory University School of Medicine and Rollins School of Public Health, Atlanta, GA, USA

12. Department of Biostatistics, T.H. Chan Harvard School of Public Health, Boston, MA, USA

13. Kaiser Permanente Mid-Atlantic Medical Group and Research Institute, Washington, D.C., USA

14. Division of Cancer Epidemiology \& Genetics, Infections and Immunoepidemiology Branch, National Cancer Institute, Rockville, MD, USA

15. Division of Infectious Diseases, Department of Medicine, University of North Carolina School of Medicine, Chapel Hill, NC, USA

16. Division of Infectious Diseases, Department of Medicine, University of Illinois Chicago School of Medicine, Chicago, IL, USA

17. Division of Infectious Diseases and Global Public Health, Department of Medicine, University of California San Diego, San Diego, CA, USA

18. Department of Ophthalmology, Wilmer Eye Institute, Johns Hopkins University School of Medicine, Baltimore MD, USA

19. Division of Infectious Diseases, Department of Medicine, Johns Hopkins University School of Medicine, Baltimore, MD, USA

20. Division of Epidemiology, Department of Medicine, Vanderbilt University Medical Center, Nashville, TN, USA

Abstract word count: 250 [250 max]

Manuscript word count: 2986 [3000 max] 
medRxiv preprint doi: https://doi.org/10.1101/2021.07.21.21260588; this version posted July 23, 2021. The copyright holder for this preprint (which was not certified by peer review) is the author/funder, who has granted medRxiv a license to display the preprint in perpetuity.

All rights reserved. No reuse allowed without permission.

Key words: HIV, CD4/CD8, cancer, lung cancer, anal cancer

Short title: CD4/CD8 ratio and cancer risk in HIV

Conferences at which data were presented: $27^{\text {th }}$ Conference on Retroviruses and Opportunistic Infections, Boston, March 2020.

Corresponding author:

Jessica L. Castilho, M.D., M.P.H.

Vanderbilt University Medical Center

A2200 Medical Center North

$116121^{\text {st }}$ Avenue South

Nashville, TN 37232

Tel: (615) 322-2035

Fax: (615) 343-6160

E-mail: jessica.castilho@vumc.org 
medRxiv preprint doi: https://doi.org/10.1101/2021.07.21.21260588; this version posted July 23, 2021. The copyright holder for this preprint (which was not certified by peer review) is the author/funder, who has granted medRxiv a license to display the preprint in perpetuity.

All rights reserved. No reuse allowed without permission.

\begin{abstract}
Background: Independent of CD4 cell count, low CD4/CD8 ratio in people with HIV (PWH) is associated with deleterious immune senescence, activation, and inflammation, which may contribute to carcinogenesis and excess cancer risk. We examined whether low CD4/CD8 ratios predicted cancer among PWH in the USA and Canada.
\end{abstract}

Methods: We examined all cancer-free PWH with one or more CD4/CD8 values from NAACCORD observational cohorts with validated cancer diagnoses between 1998-2016. We evaluated the association between time-lagged CD4/CD8 ratio and risk of specific cancers in multivariable, time-updated Cox proportional hazard models using restricted cubic spines. Models were adjusted for age, sex, race/ethnicity, hepatitis C virus, and time-updated CD4 cell count, HIV RNA, and history of AIDS-defining illness.

Results: Among 83,893 PWH, there were 5,628 incident cancers, including lung cancer $(\mathrm{n}=755)$, Kaposi sarcoma (KS, n=501), non-Hodgkin lymphoma (NHL, n=497), and anal cancer ( $\mathrm{n}=439)$. Median age at cohort entry was 43 years, $87 \%$ were male, and $43 \%$ were white. Overall median six-month lagged CD4/CD8 ratio was 0.52 (interquartile range: 0.30-0.82). Compared with sixmonth lagged $\mathrm{CD} 4 / \mathrm{CD} 8=0.80, \mathrm{CD} 4 / \mathrm{CD} 8=0.30$ was associated with increased risk of any incident cancer (adjusted hazard ratio $=1.24$ [95\% confidence interval: $1.14-1.35]$ ). CD4/CD8 ratio was also inversely associated with NHL, KS, lung cancer, anal cancer, and colorectal cancer in adjusted analyses (all $p<0.05$ ). Results were similar using 12-, 18-, and 24-month lagged CD4/CD8 values.

Conclusions: Low CD4/CD8 ratio up to 24 months prior to cancer diagnosis was independently associated with increased cancer risk in PWH and may serve as a clinical biomarker. 
medRxiv preprint doi: https://doi.org/10.1101/2021.07.21.21260588; this version posted July 23, 2021. The copyright holder for this preprint (which was not certified by peer review) is the author/funder, who has granted medRxiv a license to display the preprint in perpetuity.

All rights reserved. No reuse allowed without permission.

\section{Introduction}

While people with HIV (PWH) are living longer with use of effective antiretroviral therapy (ART), they remain at an increased risk for cancer compared to the general U.S. population [15]. In addition to AIDS-defining cancers (ADCs) including Kaposi sarcoma, non-Hodgkin lymphomas (NHL) and cervical cancer, the risk of several non-AIDS-defining cancers (NADCs) such as liver, lung, anal, oral pharyngeal cancers and Hodgkin lymphoma remains increased in PWH [6-9]. Cancer mortality is also significantly higher among PWH compared to the general population $[10,11]$. Approximately $10 \%$ of all deaths among PWH prescribed ART in the U.S. between 1995-2009 were attributed to cancer; with NHL, lung, and liver cancer contributing the highest number of deaths [10].

Increased cancer risk in PWH is attributed to HIV-induced immunodeficiency, immune dysfunction, coinfection with oncogenic viruses, and high prevalence of behavioral risk factors for cancer, including smoking [12-15]. Altered immunity, not simply immunodeficiency, is one proposed mechanism driving the excess risk of cancer in PWH. Decreased immune surveillance and increased cellular replication associated with immune senescence and activation, and inflammation increase carcinogenesis $[16,17]$. The prevalence of oncogenic viruses, such as human papillomavirus (HPV) and hepatitis C virus (HCV), is high among PWH [15]. Lastly, $20 \%$ of all incident cancers among PWH is attributed to smoking [14].

In PWH, CD4 and CD8 measures are generally readily available clinical tests. Low CD4/CD8 ratio inversely correlates with T lymphocyte replicative senescence, activation and exhaustion, each a measure of immunosenescence and systemic inflammation [18-20]. Low $\mathrm{CD} 4 / \mathrm{CD} 8$ ratio is also associated with older age, cytomegalovirus (CMV) coinfection, and low CD4 nadir in PWH, and has been associated with risk of non-AIDS outcomes [18, 21-27]. We 
medRxiv preprint doi: https://doi.org/10.1101/2021.07.21.21260588; this version posted July 23, 2021. The copyright holder for this preprint (which was not certified by peer review) is the author/funder, who has granted medRxiv a license to display the preprint in perpetuity.

All rights reserved. No reuse allowed without permission.

sought to determine whether CD4/CD8 ratio, as a marker of immune dysregulation, was associated with cancer risk, with the hypothesis that CD4/CD8 ratio would be inversely associated with incident cancer diagnoses among PWH.

\section{Methods}

This study examined incident cancer diagnoses and longitudinal CD4/CD8 data from the North American AIDS Cohort Collaboration on Research and Design (NA-ACCORD), the largest multi-site consortium of observational clinical cohorts of PWH in the United States and Canada [28]. Participating cohorts contributed patient-level demographic, behavioral, and clinical data including diagnoses, medications, and laboratory values to the central Data Management Center for quality assessment and harmonization. All cancer diagnoses in the NA-ACCORD were validated by standardized medical record documentation that included abstraction of histopathologic information or linkage with cancer registries [4]. The institutional review boards at participating cohorts, Johns Hopkins University, and Vanderbilt University have approved human subject activities conducted within the NA-ACCORD related to this study.

NA-ACCORD includes $\mathrm{PWH} \geq 18$ years of age with at least two clinic visits within the first year of cohort enrollment. A total of 22 observational cohorts in NA-ACCORD collected validated cancer diagnoses from January 1998-December 2016. This study excluded seven cohorts where $\geq 25 \%$ of PWH had no CD8 cell counts recorded. All PWH with any cancer diagnosis before or within the first six months of cohort entry or a cancer with an unknown diagnosis date were excluded. Only PWH with a minimum of 12 months of clinic follow-up were included in the primary analysis to allow for our lagged exposure (see below). PWH contributed person-time of observation from six months after cohort entry until cancer diagnosis, 
medRxiv preprint doi: https://doi.org/10.1101/2021.07.21.21260588; this version posted July 23, 2021. The copyright holder for this preprint (which was not certified by peer review) is the author/funder, who has granted medRxiv a license to display the preprint in perpetuity.

All rights reserved. No reuse allowed without permission.

death, last laboratory value if $>18$ months before cohort data closure, or date of validated cancer data closure. PWH with extended periods out of care (defined as >18 months without laboratory values) were allowed to re-enter the observation period.

Our primary outcomes were incident invasive cancers, excluding basal and squamous cell skin cancers, which are not routinely captured in cancer registries and may not be completely ascertained in our data. We examined any incident cancer diagnosis as a composite outcome as well as individual AIDS-defining cancers (Kaposi sarcoma, non-Hodgkin lymphoma, and cervical cancer), HIV-associated cancers (Hodgkin lymphoma, liver cancer, anal cancer, head and neck cancer, and lung cancer), and the most common cancers in the general U.S. population (breast cancer, colorectal cancer, and prostate cancer). For those PWH with multiple cancers, only the first diagnosis of each cancer was included as an outcome.

We used time-updated, lagged values of CD4/CD8 ratio in our time-to-event analyses. We hypothesized a delayed effect of CD4/CD8 ratio and cancer diagnosis; therefore, we evaluated lagged CD4/CD8 ratio values, referencing the values recorded during defined intervals in the past in estimation of cancer risk during observation time (Supplemental Figure 1). Individual observation time was constructed based upon laboratory values and their corresponding dates of measurement. CD4 and CD8 cell counts were time-varying and carried forward for a maximum of one year. In the setting of a gap in laboratory values of more than one year, the remaining person-time was coded as missing laboratory values and the gap period was excluded from the analysis. Person-time of observation, including cancer diagnoses occurring during periods of missing laboratory values, were censored. Our primary analysis examined six-month lagged $\mathrm{CD} 4 / \mathrm{CD} 8$ ratio value to minimize risk of reverse causality of CD4/CD8 ratio changes and cancer 
medRxiv preprint doi: https://doi.org/10.1101/2021.07.21.21260588; this version posted July 23, 2021. The copyright holder for this preprint

diagnosis. Given that the time between low CD4/CD8 ratio and cancer development is not known, we repeated analyses using 12-month, 18-month, and 24-month lagged CD4/CD8 ratio.

We used multivariable Cox proportional hazards models to calculate cause-specific hazard ratios for CD4/CD8 ratio and cancer risk [29]. Individuals were followed to their first cancer outcome or were censored if they died or had no event during their observed follow-up time. Multivariable models included covariates selected a priori based on clinical knowledge and number of events (degrees of freedom) as potential confounders of the association between CD4/CD8 ratio and the cancer outcome of interest, other cancers, or death. All models included age at study entry, race/ethnicity (White, Black, Latinx or other), sex, year of cohort entry, history of $\mathrm{HCV}$ infection at any point during clinical follow-up, and time-varying status of history of any AIDS-defining illness (other than an ADC). Models examining risk factors for liver cancer additionally adjusted for history of hepatitis B virus (HBV) infection, history of injection drug use (IDU), history of heavy alcohol use (defined by documented diagnoses, medical record review, and survey results), and time-varying, lagged diagnosis of cirrhosis. Time-varying lagged CD4 cell count and HIV RNA were included to examine the effect of CD4/CD8 ratio (independent of absolute CD4 cell count) and to account for the strong correlation between HIV viremia and the absolute CD4 and CD8 cell count. HIV RNA $\left(\log _{10}\right.$ transformed), CD4 count (square root transformed), and CD4/CD8 ratio (natural logarithm transformed) were modeled as time-varying covariates. HIV RNA was used as a surrogate marker for time-varying ART use and values below than the limit of detection were calculated as (lower limit of detection - 1 copy/mL). To avoid assuming a linear relationship, most continuous covariates were included in the models using restricted cubic splines, including CD4/CD8 ratio values as there are no specific values associated with clinical outcomes in PWH [30]. For 
medRxiv preprint doi: https://doi.org/10.1101/2021.07.21.21260588; this version posted July 23, 2021. The copyright holder for this preprint (which was not certified by peer review) is the author/funder, who has granted medRxiv a license to display the preprint in perpetuity.

All rights reserved. No reuse allowed without permission.

selection of consistent referent values for comparison of effects for each separate cancer analysis, we present adjusted hazard ratios (aHR) for the CD4/CD8 ratio comparing the 0.3 and 0.5 to 0.8 values which were selected for ease of comparison and approximation of the $25^{\text {th }}, 50^{\text {th }}$, and $75^{\text {th }}$ percentile values of the six-month lagged CD4/CD8 ratio values for the study cohort. P-values were computed using Wald statistics. Models for sex-specific cancers (prostate and cervical) included only PWH of the relevant sex; breast cancer analyses included only females. Inclusion of all pre-specified covariates was dependent upon the number of cancer endpoints and reduced for breast and cervical cancer to avoid overfitting models. We stratified all Cox analyses by cohort to allow for separate baseline hazards.

In a sensitivity analysis, we fit models that included HIV acquisition risk factor; smoking status (ever vs. never); and six-month lagged, time-varying body mass index (BMI). When smoking status or alcohol was missing for individual patients, we used covariates and the outcome data to multiply impute (20 times) using predictive mean matching. Estimates from the imputation-specific analyses were then combined using Rubin's rule [31].

All analyses were conducted in R version 3.6.2 and analysis code is available online at https://biostat.app.vumc.org/wiki/Main/ArchivedAnalyses. All $p$ values were two-sided. NAACCORD data are publicly available for collaborative use, online at https://naaccord.org/.

\section{Results}

The creation of the study population from the 15 eligible NA-ACCORD cohorts with contributing data is shown in Supplemental Figure 2. Characteristics of PWH included in the primary and sensitivity analyses are shown in Table 1 . In the primary analysis using six-month lagged laboratory data, 83,893 PWH contributed 744,415 person-years of observation and 5,628 
medRxiv preprint doi: https://doi.org/10.1101/2021.07.21.21260588; this version posted July 23, 2021. The copyright holder for this preprint (which was not certified by peer review) is the author/funder, who has granted medRxiv a license to display the preprint in perpetuity.

All rights reserved. No reuse allowed without permission.

incident cancer diagnoses (excluding non-melanoma skin cancers). Of all observation time, 167,816 person-years $(22.5 \%)$ were censored for missing CD4/CD8 ratio or HIV RNA levels. The median six-month lagged CD4/CD8 ratio was 0.52 (interquartile range: $0.30-0.82$ ). $\mathrm{PWH}$ in both the primary and sensitivity analyses were predominantly male and less than half were white race. The median CD4 cell count, HIV RNA, and history of AIDS-defining illness at the start of observation time was similar between PWH included in the primary and sensitivity analyses. Table 1 also shows the frequency of the most common cancers diagnosed. For the primary analyses, there were a total of 5,628 incident cancers, of which 1,045 (19\%) were an ADC. Of the NADCs, prostate cancer $(n=817)$, lung cancer $(n=755)$ and anal cancer $(n=439)$ were the most frequent.

Results of our primary analysis including the adjusted hazard ratios (aHR) and 95\% confidence intervals $(\mathrm{CI})$ comparing the 0.3 and $0.5 \mathrm{CD} 4 / \mathrm{CD} 8$ ratio values with the 0.8 are shown in Figure 1. There was a $24 \%$ increased risk of any incident cancer for individuals with six-month lagged CD4/CD8 ratio of 0.3 compared to 0.8 , independent of CD4 cell count, HIV RNA value, and other covariates $(\mathrm{aHR}=1.24,95 \% \mathrm{CI} 1.14-1.35)$. We observed the same pattern of increasing cancer risk with decreasing CD4/CD8 ratio for NHL, Kaposi sarcoma, lung cancer, anal cancer, and colorectal cancer. Six-month-lagged CD4/CD8 ratio was not associated with risk of cervical cancer, Hodgkin lymphoma, head and neck cancer, prostate cancer, breast cancer, nor liver cancer.

Results examining CD4/CD8 ratio values lagged at 12-months, 18-months, and 24-months as well as the six-months used in the primary analysis are shown in Supplemental Table 1. Adjusted hazard ratios for cancers common among PWH along a continuum of CD4/CD8 values compared to 0.8 and using different lags are shown in Figure 2. Overall, we observed differing 
medRxiv preprint doi: https://doi.org/10.1101/2021.07.21.21260588; this version posted July 23, 2021. The copyright holder for this preprint (which was not certified by peer review) is the author/funder, who has granted medRxiv a license to display the preprint in perpetuity.

All rights reserved. No reuse allowed without permission.

patterns of timing of low CD4/CD8 ratio and cancer risk across cancer types. As shown in Figure 2, low CD4/CD8 ratio values from six- to 24-months prior were all associated with increased risk of any cancer ( $p<0.001$ for all time points). Similarly, low CD4/CD8 ratio was strongly associated with increased risk of anal and lung cancers across all lagged time points $(p<0.001$ for all time points for both cancers) (Figure 2). In contrast, while statistically significant at all lagged time points, low CD4/CD8 ratio was associated with highest risk of NHL in the six months prior, compared to 24 months (Figure $2 \mathrm{~d}, p<0.01$ for all lagged time points). In contrast, low CD4/CD8 ratio six months prior was not associated with risk of Hodgkin lymphoma ( $p$ $=0.88)$ but was associated with increased risk 12 and 18 -months prior $(p=0.052$ and 0.015 , respectively) (Figure 2). Additional figures for specific cancer types and lagged CD4/CD8 ratio values are shown in Supplemental Figure 3.

The multivariable analyses which included the subset of patients with available smoking, alcohol, HIV acquisition risk factor, and BMI data that assessed six-month lagged CD4/CD8 ratio and cancer risk are shown in Figure 3. Given the smaller number of cancers included in the sensitivity analyses, only any cancer, NHL, Kaposi sarcoma, lung cancer, and anal cancer were assessed in multivariable models to avoid over-fitting. The inverse association between low CD4/CD8 ratio and increased cancer risk persisted for any cancer, NHL, lung cancer, and anal cancer but was attenuated and no longer statistically significant for Kaposi sarcoma.

\section{Discussion}

In this large study of PWH in care and with high uptake of ART in the United States and Canada between 1998-2016, we found that low, time-lagged CD4/CD8 ratio was associated with increased risk of incident cancer diagnoses after accounting for CD4 cell count, HIV viral load, 
medRxiv preprint doi: https://doi.org/10.1101/2021.07.21.21260588; this version posted July 23, 2021. The copyright holder for this preprint

HIV acquisition risk, smoking, and other factors. The inverse association between CD4/CD8 ratio and cancer risk was observed for a number of specific cancers, including three of the most common cancers among PWH in the U.S.: NHL, lung cancer, and anal cancer. The association between low CD4/CD8 ratio and risk of cancer was not uniform, nor was the association exclusive for cancers associated with oncogenic viruses. Given the robust association up to 24months prior to cancer diagnosis, CD4/CD8 ratio may indicate underlying immune dysfunction affecting carcinogenesis and inform cancer screening and prevention interventions among PWH. Low CD4/CD8 ratio predicted risk of any cancer, independent of age, sex, CD4 cell count, HIV viral load, chronic HCV infection, and smoking history measures. Among PWH, low CD4/CD8 ratio is associated with older age; low CD4 nadir; male sex; HIV acquisition risk factors (particularly for MSM); chronic viral co-infection (including HCV and cytomegalovirus); and large HIV reservoir [27, 32-35]. Despite immune reconstitution from effective ART, PWH with low CD4/CD8 ratio have increased measures of adaptive immunosenescence including skewed T-lymphocytes populations from naïve to terminally differentiated phenotypes, higher expression of cellular markers of CD8 T cell activation and senescence, and higher kynurenine/trypotphan ratio $[18,20]$. Low CD4/CD8 ratio has also been associated with increased measures of monocyte activation and systemic inflammatory measures, including IL-6, CRP, and soluble CD14 [18, 19]. Adaptive immune senescence, T cell activation, and inflammation have been identified as drivers of the excess risk of non-communicable diseases observed in PWH, including cardiovascular disease and cancers [36-39]. In PWH, low CD4/CD8 ratio has been associated with increased risk of mortality and non-communicable diseases [22, 23, 40]. Low CD4/CD8 has been associated with risk of NADCs in smaller studies of PWH [24, 41]. To our knowledge, this is the largest study to demonstrate an independent association 
medRxiv preprint doi: https://doi.org/10.1101/2021.07.21.21260588; this version posted July 23, 2021. The copyright holder for this preprint

between low CD4/CD8 ratio and cancer risk in $\mathrm{PWH}$, which we found was consistent up to twoyears preceding the cancer diagnosis.

We found that NHL, lung cancer and anal cancer, three of the leading causes of cancerrelated morbidity and mortality in PWH in the U.S., were strongly and consistently associated with low CD4/CD8 ratio [42]. Both lung cancer and anal cancer have higher incidence and are diagnosed at younger ages in PWH compared to the general population, suggesting accelerated aging biology, such as immunosenescence, may contribute to cancer risk in PWH [6, 8, 43, 44]. The large Veterans Aging Cohort Study found an independent association between low, cumulatively-averaged CD4/CD8 ratio and lung cancer risk in U.S veterans with HIV [25]. Our results are consistent with their findings; supporting the hypothesis that immune dysfunction, independent of oncogenic viral activity, may contribute to cancer risk in PWH.

This is the largest study to show low peripheral CD4/CD8 ratio predicts anal cancer risk, independent of HIV acquisition risk factor, smoking, or immunodeficiency. A single-center study of PWH observed that low CD4/CD8 ratio nadir and CD4/CD8 proximal to anal cancer screening were associated with high-grade anal dysplasia and cancer; however, analyses did not adjust for concurrent CD4 cell count [45]. The ratio of CD4/CD8 tumor-infiltrating and stromal lymphocytes in tissue biopsies of HPV-associated pre-cancers of the cervix, anus, and head and neck have been associated with disease progression or regression; however, circulating CD4/CD8 ratio has not been evaluated in anal pre-cancers [46-49]. ART has not been shown to be associated with the regression or clearance of anal lesions, suggesting immune restoration does not entirely eliminate the increased risk $[50,51]$. That we did not find an association between $\mathrm{CD} 4 / \mathrm{CD} 8$ ratio and cervical cancer may be due to the small number of cancer cases in this cohort. Additionally, we did not find a significant association between CD4/CD8 ratio and 
medRxiv preprint doi: https://doi.org/10.1101/2021.07.21.21260588; this version posted July 23, 2021. The copyright holder for this preprint (which was not certified by peer review) is the author/funder, who has granted medRxiv a license to display the preprint in perpetuity.

All rights reserved. No reuse allowed without permission.

head and neck cancer; however, we could not distinguish cases that were associated with HPV.

Further research is needed to assess CD4/CD8 ratio and HPV-associated and HPV-negative head and neck cancers.

There are important limitations of this study. The study population was disproportionately male, not only resulting in low numbers of cervical cancer and breast cancer but limiting our ability to examine CD4/CD8 ratio and cancer risk in women with HIV more generally. HIV acquisition risk factor and behavioral data including smoking history were not available from all cohorts, though results from our sensitivity analyses were generally consistent with those from the primary analyses. However, for lung cancer in particular, our results may still be affected by residual confounding from smoking given the limited smoking information in our cohort. CD4/CD8 ratio is lower in settings of chronic viral infections and our data on prevalent oncogenic viruses were limited to $\mathrm{HCV}$ and $\mathrm{HBV}$. The cancer most associated with these viruses, liver cancer, was not significantly associated with CD4/CD8 ratio in multivariable models. Seroprevalence of CMV, human herpes virus 8 (Kaposi sarcoma), Epstein-Barr virus (Hodgkin lymphoma and NHL), or infection with high-risk HPV (cervical, anal, and head and neck cancers) is not universally collected in clinical care of PWH. Our data may also be subject to misclassification bias as a result of carrying-forward CD4/CD8 data and periods of missing CD4/CD8 data.

In the largest study of PWH in the U.S. and Canada, we found that lagged, low CD4/CD8 ratio was associated with increased risk of certain incident cancers. Low CD4/CD8 ratio was associated with increased risk of NHL, lung cancer, and anal cancer. The consistency of association observed up to 24-months prior to cancer diagnosis suggests CD4/CD8 ratio may be a useful biomarker for screening for lung and anal cancer in PWH where the average age at 
medRxiv preprint doi: https://doi.org/10.1101/2021.07.21.21260588; this version posted July 23, 2021. The copyright holder for this preprint (which was not certified by peer review) is the author/funder, who has granted medRxiv a license to display the preprint in perpetuity.

All rights reserved. No reuse allowed without permission.

diagnosis is younger than in the general population. Further investigation into the roles of immunosenescence, immune activation, and inflammation and cancer risk observed in $\mathrm{PWH}$ is needed.

\section{Funding}

The content is solely the responsibility of the authors and does not necessarily represent the official views of the National Institutes of Health. This work was supported by National Institutes of Health grants P30CA068485-23S3, K23AI120875, K07CA225404, U01AI069918, F31AI124794, F31DA037788, G12MD007583, K01AI093197, K01AI131895, K23EY013707, K24AI065298, K24AI118591, K24DA000432, KL2TR000421, N01CP01004, N02CP055504, N02CP91027, P30AI027757, P30AI027763, P30AI027767, P30AI036219, P30AI050409, P30AI050410, P30AI094189, P30AI1 10527, P30MH62246, R01AA016893, R01DA011602, R01DA012568, R01 AG053100, R24AI067039, R34DA045592, U01AA013566, U01AA020790, U01AI038855, U01AI038858, U01AI068634, U01AI068636, U01AI069432, U01AI069434, U01DA03629, U01DA036935, U10EY008057, U10EY008052, U10EY008067, U01HL146192, U01HL146193, U01HL146194, U01HL146201, U01HL146202, U01HL146203, U01HL146204, U01HL146205, U01HL146208, U01HL146240, U01HL146241, U01HL146242, U01HL146245, U01HL146333, U24AA020794, U54GM133807, UL1RR024131, UL1TR000004, UL1TR000083, UL1TR002378, Z01CP010214 and Z01CP010176; contracts CDC-200-2006-18797 and CDC-200-2015-63931 from the Centers for Disease Control and Prevention, USA; contract 90047713 from the Agency for Healthcare Research and Quality, USA; contract 90051652 from the Health Resources and Services Administration, USA; the Grady Health System; grants CBR-86906, CBR-94036, HCP- 
medRxiv preprint doi: https://doi.org/10.1101/2021.07.21.21260588; this version posted July 23, 2021. The copyright holder for this preprint

(which was not certified by peer review) is the author/funder, who has granted medRxiv a license to display the preprint in perpetuity.

All rights reserved. No reuse allowed without permission.

97105 and TGF-96118 from the Canadian Institutes of Health Research, Canada; Ontario

Ministry of Health and Long Term Care, and the Government of Alberta, Canada. Additional support was provided by the National Institute Of Allergy And Infectious Diseases (NIAID),

National Cancer Institute (NCI), National Heart, Lung, and Blood Institute (NHLBI), Eunice

Kennedy Shriver National Institute Of Child Health \& Human Development (NICHD), National Human Genome Research Institute (NHGRI), National Institute for Mental Health (NIMH) and

National Institute on Drug Abuse (NIDA), National Institute On Aging (NIA), National Institute Of Dental \& Craniofacial Research (NIDCR), National Institute Of Neurological Disorders And Stroke (NINDS), National Institute Of Nursing Research (NINR), National Institute on Alcohol Abuse and Alcoholism (NIAAA), National Institute on Deafness and Other Communication Disorders (NIDCD), and National Institute of Diabetes and Digestive and Kidney Diseases (NIDDK). These data were collected by cancer registries participating in the National Program of Cancer Registries (NPCR) of the Centers for Disease Control and Prevention (CDC).

\section{Notes}

\section{Role of the funding sources:}

The funding sources of the study had no role in study design, data collection, data analysis, data interpretation, or writing of the report.

\section{Author disclosures:}

MJS has received a grant to his institution from Gilead Sciences for HIV research not directly related to this manuscript. VCM received research grants from CDC, Gilead Sciences, NIH, VA, and ViiV, received honoraria from Eli Lilly and Company, served as an advisory board member 
medRxiv preprint doi: https://doi.org/10.1101/2021.07.21.21260588; this version posted July 23, 2021. The copyright holder for this preprint (which was not certified by peer review) is the author/funder, who has granted medRxiv a license to display the preprint in perpetuity.

All rights reserved. No reuse allowed without permission.

for Eli Lilly and Company and Novartis and participated as a study section chair for the NIH. JG is an ad Hoc member of Canadian national HIV advisory Boards to Merck, Gilead and ViiV.

Data availability:

NA-ACCORD welcomes interested investigators to collaborate with us for use of our data.

Please visit https://naaccord.org/ for additional information.

NA-ACCORD Collaborating Cohorts and Representatives:

AIDS Clinical Trials Group Longitudinal Linked Randomized Trials: Constance A. Benson and Ronald J. Bosch

AIDS Link to the IntraVenous Experience: Gregory D. Kirk

Emory-Grady HIV Clinical Cohort: Vincent Marconi and Jonathan Colasanti

Fenway Health HIV Cohort: Kenneth H. Mayer and Chris Grasso

HAART Observational Medical Evaluation and Research: Robert S. Hogg, Viviane Lima, P.

Richard Harrigan, Julio SG Montaner, Benita Yip, Julia Zhu, and Kate Salters

HIV Outpatient Study: Kate Buchacz and Jun Li

HIV Research Network: Kelly A. Gebo and Richard D. Moore

Johns Hopkins HIV Clinical Cohort: Richard D. Moore

John T. Carey Special Immunology Unit Patient Care and Research Database, Case

Western Reserve University: Jeffrey M. Jacobson

Kaiser Permanente Mid-Atlantic States: Michael A. Horberg

Kaiser Permanente Northern California: Michael J. Silverberg

Longitudinal Study of Ocular Complications of AIDS: Jennifer E. Thorne 
medRxiv preprint doi: https://doi.org/10.1101/2021.07.21.21260588; this version posted July 23, 2021. The copyright holder for this preprint

(which was not certified by peer review) is the author/funder, who has granted medRxiv a license to display the preprint in perpetuity.

All rights reserved. No reuse allowed without permission.

MACS/WIHS Combined Cohort Study: Todd Brown, Phyllis Tien, and Gypsyamber D’Souza

Maple Leaf Medical Clinic: Graham Smith, Mona Loutfy, and Meenakshi Gupta

The McGill University Health Centre, Chronic Viral Illness Service Cohort: Marina B.

Klein

Multicenter Hemophilia Cohort Study-II: Charles Rabkin

Ontario HIV Treatment Network Cohort Study: Abigail Kroch, Ann Burchell, Adrian Betts, and Joanne Lindsay

Parkland/UT Southwestern Cohort: Ank Nijhawan

Retrovirus Research Center, Universidad Central del Caribe, Bayamon Puerto Rico: Angel

M. Mayor

Southern Alberta Clinic Cohort: M. John Gill

Study of the Consequences of the Protease Inhibitor Era: Jeffrey N. Martin

Study to Understand the Natural History of HIV/AIDS in the Era of Effective Therapy: Jun

Li and John T. Brooks

University of Alabama at Birmingham 1917 Clinic Cohort: Michael S. Saag, Michael J.

Mugavero, and James Willig

University of California at San Diego: Laura Bamford and Maile Karris

University of North Carolina at Chapel Hill HIV Clinic Cohort: Joseph J. Eron and Sonia

Napravnik

University of Washington HIV Cohort: Mari M. Kitahata and Heidi M. Crane

Vanderbilt Comprehensive Care Clinic HIV Cohort: Timothy R. Sterling, David Haas, Peter

Rebeiro, and Megan Turner

Veterans Aging Cohort Study: Lesley Park and Amy Justice 
medRxiv preprint doi: https://doi.org/10.1101/2021.07.21.21260588; this version posted July 23, 2021. The copyright holder for this preprint

(which was not certified by peer review) is the author/funder, who has granted medRxiv a license to display the preprint in perpetuity.

All rights reserved. No reuse allowed without permission.

\section{NA-ACCORD Study Administration:}

Executive Committee: Richard D. Moore, Keri N. Althoff, Stephen J. Gange, Mari M.

Kitahata, Jennifer S. Lee, Michael S. Saag, Michael A. Horberg, Marina B. Klein, Rosemary G.

McKaig, and Aimee M. Freeman

Administrative Core: Richard D. Moore, Keri N. Althoff, and Aimee M. Freeman

Data Management Core: Mari M. Kitahata, Stephen E. Van Rompaey, Heidi M. Crane, Liz

Morton, Justin McReynolds, and William B. Lober

Epidemiology and Biostatistics Core: Stephen J. Gange, Jennifer S. Lee, Brenna Hogan, Bin

You, Elizabeth Humes, Lucas Gerace, Cameron Stewart, and Sally Coburn 
medRxiv preprint doi: https://doi.org/10.1101/2021.07.21.21260588; this version posted July 23, 2021. The copyright holder for this preprint

(which was not certified by peer review) is the author/funder, who has granted medRxiv a license to display the preprint in perpetuity.

All rights reserved. No reuse allowed without permission.

\section{Figure Legends:}

Figure 1. Adjusted hazard ratios and $95 \%$ confidence interval for cancer outcomes comparing the 6-month lagged, time-varying CD4/CD8 ratio values.

Legend: Models for any cancer, lung cancer, Non-Hodgkin lymphoma, Hodgkin lymphoma, Kaposi sarcoma cancer, anal cancer, head and neck cancer, colorectal cancer included the covariates of age, sex, race, year of cohort entry, any history of chronic hepatitis $\mathrm{C}$ virus infection, and time-varying and time-updated CD4/CD8 ratio, CD4 cell count, HIV RNA, and history of AIDS-defining illness. The multivariable model for liver cancer included the covariates of age, sex, race, year of cohort entry, any history of chronic hepatitis $\mathrm{C}$ virus infection, history of chronic hepatitis B virus infection, history of heavy alcohol use, history of injection drug use, and time-varying and time-updated CD4/CD8 ratio, CD4 cell count, HIV RNA, history of AIDS-defining illness, and history of cirrhosis. The multivariable model for prostate cancer included only males and covariates age, race, year of cohort entry, any history of chronic hepatitis $\mathrm{C}$ virus infection, and time-varying and time-updated CD4/CD8 ratio, CD4 cell count, HIV RNA, and history of AIDS-defining illness. Models for breast cancer and cervical cancer included only females and included age, race (white vs. non-white), and time-varying and lagged CD4/CD8 ratio, CD4 cell count, HIV RNA, and history of AIDS-defining illness.

Figure 2. Adjusted hazard ratio for cancer and CD4/CD8 ratios lagged six, twelve, 18, and 24months.

Legend: Adjusted hazard ratio for CD4/CD8 ratio values lagged six months (solid orange lines), 12 months (dashed green lines), 18 months (dashed teal lines), and 24 months (dashed purple 
medRxiv preprint doi: https://doi.org/10.1101/2021.07.21.21260588; this version posted July 23, 2021. The copyright holder for this preprint (which was not certified by peer review) is the author/funder, who has granted medRxiv a license to display the preprint in perpetuity.

All rights reserved. No reuse allowed without permission.

lines) for the following cancers (number of events for each model): (a) Any cancer (six months $\mathrm{n}=4,940 ; 12$ months $\mathrm{n}=4,597 ; 18$ months $\mathrm{n}=4,308 ; 24$ months $\mathrm{n}=4,043$ ); (b) Anal cancer ( $\operatorname{six}$ months $n=395 ; 12$ months $n=375 ; 18$ months $n=361 ; 24$ months $n=340$ ); (c) Lung cancer (six months $n=664 ; 12$ months $n=645 ; 18$ months $n=645 ; 24$ months $n=564$ ); (d) NHL (six months $\mathrm{n}=433 ; 12$ months $\mathrm{n}=382 ; 18$ months $\mathrm{n}=333 ; 24$ months $\mathrm{n}=310$ ); (e) Hodgkin lymphoma ( months $n=157 ; 12$ months $n=145 ; 18$ months $n=143 ; 24$ months $n=124)$. Models included the covariates of age, year of cohort entry, sex, race, any history of chronic hepatitis $\mathrm{C}$ virus infection, and time-varying and lagged CD4/CD8 ratio, CD4 cell count, HIV RNA, and history of AIDS-defining illness.

Figure 3. Sensitivity analyses for the adjusted hazard ratios and $95 \%$ confidence interval for cancer outcomes comparing the 6-month lagged, time-varying CD4/CD8 ratio values.

Legend: Only models for any cancer, lung cancer, Non-Hodgkin lymphoma, Kaposi sarcoma cancer, and anal cancer performed due to number of events. All models included the covariates of age, sex, race, year of cohort entry, any history of chronic hepatitis C virus infection, history of smoking, history of heavy alcohol use, HIV acquisition risk factor, and time-varying and timeupdated CD4/CD8 ratio, CD4 cell count, HIV RNA, history of AIDS-defining illness, and BMI. 
medRxiv preprint doi: https://doi.org/10.1101/2021.07.21.21260588; this version posted July 23, 2021. The copyright holder for this preprint (which was not certified by peer review) is the author/funder, who has granted medRxiv a license to display the preprint in perpetuity.

\section{References}

1. Samji H, Cescon A, Hogg RS, et al. Closing the gap: increases in life expectancy among treated HIV-positive individuals in the United States and Canada. PLoS One 2013;8(12):e81355. 2. Engels EA, Biggar RJ, Hall HI, et al. Cancer risk in people infected with human immunodeficiency virus in the United States. Int J Cancer 2008;123(1):187-94.

3. Hessol NA, Seaberg EC, Preston-Martin S, et al. Cancer risk among participants in the women's interagency HIV study. J Acquir Immune Defic Syndr 2004;36(4):978-85.

4. Silverberg MJ, Lau B, Achenbach CJ, et al. Cumulative Incidence of Cancer Among Persons With HIV in North America: A Cohort Study. Ann Intern Med 2015;163(7):507-18. 5. Althoff KN, Chandran A, Zhang J, et al. Life-Expectancy Disparities Among Adults With HIV in the United States and Canada: The Impact of a Reduction in Drug- and AlcoholRelated Deaths Using the Lives Saved Simulation Model. Am J Epidemiol 2019;188(12):20972109.

6. Hernandez-Ramirez RU, Shiels MS, Dubrow R, et al. Cancer risk in HIV-infected people in the USA from 1996 to 2012: a population-based, registry-linkage study. Lancet HIV 2017;4(11):e495-e504.

7. Patel P, Hanson DL, Sullivan PS, et al. Incidence of types of cancer among HIV-infected persons compared with the general population in the United States, 1992-2003. Ann Intern Med 2008;148(10):728-36.

8. Robbins HA, Pfeiffer RM, Shiels MS, et al. Excess cancers among HIV-infected people in the United States. J Natl Cancer Inst 2015;107(4). 
medRxiv preprint doi: https://doi.org/10.1101/2021.07.21.21260588; this version posted July 23, 2021. The copyright holder for this preprint (which was not certified by peer review) is the author/funder, who has granted medRxiv a license to display the preprint in perpetuity.

All rights reserved. No reuse allowed without permission.

9. Shiels MS, Pfeiffer RM, Gail MH, et al. Cancer burden in the HIV-infected population in the United States. J Natl Cancer Inst 2011;103(9):753-62.

10. Engels EA, Yanik EL, Wheeler W, et al. Cancer-Attributable Mortality Among People With Treated Human Immunodeficiency Virus Infection in North America. Clin Infect Dis 2017;65(4):636-643.

11. Coghill AE, Pfeiffer RM, Shiels MS, et al. Excess Mortality among HIV-Infected Individuals with Cancer in the United States. Cancer Epidemiol Biomarkers Prev 2017;26(7):1027-1033.

12. Park LS, Hernandez-Ramirez RU, Silverberg MJ, et al. Prevalence of non-HIV cancer risk factors in persons living with HIV/AIDS: a meta-analysis. Aids 2016;30(2):273-91.

13. Mdodo R, Frazier EL, Dube SR, et al. Cigarette smoking prevalence among adults with HIV compared with the general adult population in the United States: cross-sectional surveys. Ann Intern Med 2015;162(5):335-44.

14. Altekruse SF, Shiels MS, Modur SP, et al. Cancer burden attributable to cigarette smoking among HIV-infected people in North America. AIDS 2018;32(4):513-521.

15. de Martel C, Shiels MS, Franceschi S, et al. Cancers attributable to infections among adults with HIV in the United States. Aids 2015;29(16):2173-81.

16. Fulop T, Larbi A, Kotb R, et al. Immunology of aging and cancer development. Interdiscip Top Gerontol 2013;38:38-48.

17. Bottazzi B, Riboli E, Mantovani A. Aging, inflammation and cancer. Semin Immunol 2018;40:74-82.

18. Serrano-Villar S, Sainz T, Lee SA, et al. HIV-infected individuals with low CD4/CD8 ratio despite effective antiretroviral therapy exhibit altered $\mathrm{T}$ cell subsets, heightened CD8+ T 
medRxiv preprint doi: https://doi.org/10.1101/2021.07.21.21260588; this version posted July 23, 2021. The copyright holder for this preprint (which was not certified by peer review) is the author/funder, who has granted medRxiv a license to display the preprint in perpetuity.

All rights reserved. No reuse allowed without permission.

cell activation, and increased risk of non-AIDS morbidity and mortality. PLoS Pathog 2014;10(5):e1004078.

19. Sainz T, Serrano-Villar S, Diaz L, et al. The CD4/CD8 ratio as a marker T-cell activation, senescence and activation/exhaustion in treated HIV-infected children and young adults. AIDS 2013;27(9):1513-6.

20. Serrano-Villar S, Gutierrez C, Vallejo A, et al. The CD4/CD8 ratio in HIV-infected subjects is independently associated with T-cell activation despite long-term viral suppression. J Infect 2013;66(1):57-66.

21. Serrano-Villar S, Perez-Elias MJ, Dronda F, et al. Increased risk of serious non-AIDSrelated events in HIV-infected subjects on antiretroviral therapy associated with a low CD4/CD8 ratio. PLoS One 2014;9(1):e85798.

22. Castilho JL, Shepherd BE, Koethe J, et al. CD4+/CD8+ ratio, age, and risk of serious noncommunicable diseases in HIV-infected adults on antiretroviral therapy. Aids 2016;30(6):899-908.

23. Mussini C, Lorenzini P, Cozzi-Lepri A, et al. CD4/CD8 ratio normalisation and nonAIDS-related events in individuals with HIV who achieve viral load suppression with antiretroviral therapy: an observational cohort study. Lancet HIV 2015;2(3):e98-106.

24. Hema MN, Ferry T, Dupon M, et al. Low CD4/CD8 Ratio Is Associated with Non AIDSDefining Cancers in Patients on Antiretroviral Therapy: ANRS CO8 (Aproco/Copilote) Prospective Cohort Study. PLoS One 2016;11(8):e0161594.

25. Sigel K, Wisnivesky J, Crothers K, et al. Immunological and infectious risk factors for lung cancer in US veterans with HIV: a longitudinal cohort study. Lancet HIV 2017;4(2):e67e73. 
medRxiv preprint doi: https://doi.org/10.1101/2021.07.21.21260588; this version posted July 23, 2021. The copyright holder for this preprint (which was not certified by peer review) is the author/funder, who has granted medRxiv a license to display the preprint in perpetuity.

All rights reserved. No reuse allowed without permission.

26. Triplette M, Attia EF, Akgun KM, et al. A Low Peripheral Blood CD4/CD8 Ratio Is Associated with Pulmonary Emphysema in HIV. PLoS One 2017;12(1):e0170857.

27. Caby F, Guihot A, Lambert-Niclot S, et al. Determinants of a Low CD4/CD8 Ratio in HIV-1-Infected Individuals Despite Long-term Viral Suppression. Clin Infect Dis 2016;62(10):1297-1303.

28. Gange SJ, Kitahata MM, Saag MS, et al. Cohort profile: the North American AIDS Cohort Collaboration on Research and Design (NA-ACCORD). Int J Epidemiol 2007;36(2):294301.

29. Haller B, Schmidt G, Ulm K. Applying competing risks regression models: an overview. Lifetime Data Anal 2013;19(1):33-58.

30. Shepherd BE, Rebeiro PF, Caribbean C, et al. Brief Report: Assessing and Interpreting the Association Between Continuous Covariates and Outcomes in Observational Studies of HIV Using Splines. J Acquir Immune Defic Syndr 2017;74(3):e60-e63.

31. Rubin DB. Multiple Imputation for Nonresponse in Surveys. New York, New York: John Wiley and Sons; 2004.

32. Kuniholm MH, O'Brien TR, Prokunina-Olsson L, et al. Association of Hepatitis C Virus Infection With CD4/CD8 Ratio in HIV-Positive Women. J Acquir Immune Defic Syndr 2016;72(2):162-70.

33. Combes JD, Clifford GM, Egger M, et al. Human papillomavirus antibody response following HAART initiation among MSM. AIDS 2017;31(4):561-569.

34. Chun TW, Justement JS, Pandya P, et al. Relationship between the size of the human immunodeficiency virus type $1(\mathrm{HIV}-1)$ reservoir in peripheral blood CD4+ T cells and 
medRxiv preprint doi: https://doi.org/10.1101/2021.07.21.21260588; this version posted July 23, 2021. The copyright holder for this preprint (which was not certified by peer review) is the author/funder, who has granted medRxiv a license to display the preprint in perpetuity.

All rights reserved. No reuse allowed without permission.

CD4+:CD8+ T cell ratios in aviremic HIV-1-infected individuals receiving long-term highly active antiretroviral therapy. J Infect Dis 2002;185(11):1672-6.

35. Verboeket SO, Wit FW, Verheij E, et al. HIV-negative Men Who Have Sex with Men have higher CD8+ T-cell Counts and Lower CD4+/CD8+ T-cell Ratios compared to HIVnegative Heterosexual Men. J Infect Dis 2020; 10.1093/infdis/jiaa048.

36. Hearps AC, Martin GE, Rajasuriar R, et al. Inflammatory co-morbidities in HIV+ individuals: learning lessons from healthy ageing. Curr HIV/AIDS Rep 2014;11(1):20-34.

37. Kaplan RC, Sinclair E, Landay AL, et al. T cell activation predicts carotid artery stiffness among HIV-infected women. Atherosclerosis 2011;217(1):207-13.

38. Tenorio AR, Zheng Y, Bosch RJ, et al. Soluble Markers of Inflammation and Coagulation but Not T-Cell Activation Predict Non-AIDS-Defining Morbid Events During Suppressive Antiretroviral Treatment. J Infect Dis 2014; 10.1093/infdis/jiu254.

39. Deeks SG, Verdin E, McCune JM. Immunosenescence and HIV. Curr Opin Immunol 2012;24(4):501-6.

40. Serrano-Villar S, Moreno S, Fuentes-Ferrer M, et al. The CD4:CD8 ratio is associated with markers of age-associated disease in virally suppressed HIV-infected patients with immunological recovery. HIV Med 2014;15(1):40-9.

41. Lasry A, Ben-Neriah Y. Senescence-associated inflammatory responses: aging and cancer perspectives. Trends Immunol 2015;36(4):217-28.

42. Engels EA, Yanik EL, Wheeler W, et al. Cancer-Attributable Mortality Among People With Treated Human Immunodeficiency Virus Infection in North America. Clin Infect Dis 2017;65(4):636-643. 
medRxiv preprint doi: https://doi.org/10.1101/2021.07.21.21260588; this version posted July 23, 2021. The copyright holder for this preprint (which was not certified by peer review) is the author/funder, who has granted medRxiv a license to display the preprint in perpetuity.

All rights reserved. No reuse allowed without permission.

43. Shiels MS, Althoff KN, Pfeiffer RM, et al. HIV Infection, Immunosuppression, and Age at Diagnosis of Non-AIDS-Defining Cancers. Clin Infect Dis 2017;64(4):468-475.

44. Shiels MS, Cole SR, Mehta SH, et al. Lung cancer incidence and mortality among HIVinfected and HIV-uninfected injection drug users. J Acquir Immune Defic Syndr 2010;55(4):510-5.

45. Geltzeiler CB, Xu Y, Carchman E, et al. CD4/CD8 Ratio as a Novel Marker for Increased Risk of High-Grade Anal Dysplasia and Anal Cancer in HIV+ Patients: A Retrospective Cohort Study. Dis Colon Rectum 2020;63(12):1585-1592.

46. Monnier-Benoit S, Mauny F, Riethmuller D, et al. Immunohistochemical analysis of CD4+ and CD8+ T-cell subsets in high risk human papillomavirus-associated pre-malignant and malignant lesions of the uterine cervix. Gynecol Oncol 2006;102(1):22-31.

47. Wolf GT, Chepeha DB, Bellile E, et al. Tumor infiltrating lymphocytes (TIL) and prognosis in oral cavity squamous carcinoma: a preliminary study. Oral Oncol 2015;51(1):90-5. 48. Saber CN, Gronhoj Larsen C, Dalianis T, et al. Immune cells and prognosis in HPVassociated oropharyngeal squamous cell carcinomas: Review of the literature. Oral Oncol 2016;58:8-13.

49. Liu Y, Gaisa MM, Wang X, et al. Differences in the Immune Microenvironment of Anal Cancer Precursors by HIV Status and Association With Ablation Outcomes. J Infect Dis 2018;217(5):703-709.

50. Seaberg EC, Wiley D, Martinez-Maza O, et al. Cancer incidence in the multicenter AIDS Cohort Study before and during the HAART era: 1984 to 2007. Cancer 2010;116(23):5507-16. 
medRxiv preprint doi: https://doi.org/10.1101/2021.07.21.21260588; this version posted July 23, 2021. The copyright holder for this preprint (which was not certified by peer review) is the author/funder, who has granted medRxiv a license to display the preprint in perpetuity.

All rights reserved. No reuse allowed without permission.

51. Palefsky JM, Holly EA, Efirdc JT, et al. Anal intraepithelial neoplasia in the highly active antiretroviral therapy era among HIV-positive men who have sex with men. AIDS 2005;19(13):1407-14. 
medRxiv preprint doi: https://doi.org/10.1101/2021.07.21.21260588; this version posted July 23, 2021. The copyright holder for this preprint (which was not certified by peer review) is the author/funder, who has granted medRxiv a license to display the preprint in perpetuity.

All rights reserved. No reuse allowed without permission.

Table 1. Baseline patient characteristics and outcomes of PWH included in primary and sensitivity analyses of six-month-lagged laboratory data

$\begin{array}{cc}\text { Primary analysis } & \text { Sensitivity analysis } \\ \text { Total } \mathrm{N}=83,893 & \text { Total } \mathrm{N}=40,975 \\ \mathrm{~N}(\%) \text { or median (IQR) } & \mathrm{N}(\%) \text { or median (IQR) }\end{array}$

Sex

Male

$72,709(87)$

$32,420(79)$

Female

$11,184(13)$

$8,555(21)$

Age at study entry (years)

$43(35-50)$

$40(33-47)$

\begin{tabular}{lcc}
\hline Race/ethnicity & $36,294(43)$ & $19,648(48)$ \\
White & $31,252(37)$ & $12,283(30)$ \\
Black & $9,449(11)$ & $5,728(14)$ \\
Latinx & $6,898(8)$ & $3,316(8)$ \\
Other or unknown & & \\
\hline HIV transmission risk factor & $28,725(34)$ & $24,368(59)$ \\
Men who have sex with men & $16,264(19)$ & $4,200(10)$ \\
Injection drug use & $10,927(13)$ & $9,222(23)$ \\
Heterosexual & $2,015(2)$ & $1,007(2)$ \\
Other & $25,962(31)$ & $2,178(5)$ \\
\hline Unknown or missing & $17,855(21)$ & $6,816(16)$ \\
\hline Chronic hepatitis C virus infection & $5,991(7)$ & $11,500(28)$ \\
\hline Chronic hepatitis B virus infection & $24,623(29)$ & \\
\hline Any history of heavy alcohol use & & \\
\hline
\end{tabular}


medRxiv preprint doi: https://doi.org/10.1101/2021.07.21.21260588; this version posted July 23, 2021. The copyright holder for this preprint (which was not certified by peer review) is the author/funder, who has granted medRxiv a license to display the preprint in perpetuity.

\begin{tabular}{|c|c|c|}
\hline Any history of tobacco use $\mathrm{b}^{\mathrm{b}}$ & $28,373(34)$ & $24,201(59)$ \\
\hline CD4 cell count, cells/uL ${ }^{\mathrm{c}}$ & $413(243-610)$ & $433(262-631)$ \\
\hline CD4/CD8 ratio $^{d}$ & $0.47(0.27-0.76)$ & $0.50(0.29-0.78)$ \\
\hline $\log _{10}$ HIV RNA, copies/mL & $2.3(1.7-3.9)$ & $2.1(1.7-3.8)$ \\
\hline \multicolumn{3}{|l|}{ HIV RNA, copies/mL $\mathrm{mL}^{\mathrm{e}}$} \\
\hline$<500$ & $41,470(58)$ & $23,670(60)$ \\
\hline $500-4999$ & $9807(14)$ & $5,187(13)$ \\
\hline$\geq 5000$ & $19,844(28)$ & $10,784(27)$ \\
\hline Body mass index, $\mathrm{kg} / \mathrm{m}^{2} \mathrm{f}$ & $25.2(22.7-28.5)$ & $25.2(22.6-28.5)$ \\
\hline History of AIDS-defining illness & $11,438(14)$ & $7,035(17)$ \\
\hline \multicolumn{3}{|l|}{ Geographic region of clinical care ${ }^{\mathrm{g}}$} \\
\hline US Northeast & $10,788(13)$ & $3,632(9)$ \\
\hline US Midwest & $7,403(9)$ & $2,993(7)$ \\
\hline US Southeast & $20,483(24)$ & $7,283(18)$ \\
\hline US West & $28,363(33)$ & $19,209(47)$ \\
\hline US Southwest & $4,444(5)$ & $111(0)$ \\
\hline US Puerto Rico \& Virgin Islands & $585(1)$ & $2(0)$ \\
\hline Canada & $6,733(8)$ & $3,293(8)$ \\
\hline Other & $12(0)$ & $2(0)$ \\
\hline Unknown & $5,082(6)$ & $4,450(11)$ \\
\hline Duration of follow-up, years & $8.5(4.0-13.8)$ & $7.7(3.6-12.7)$ \\
\hline Initiated ART before study exit ${ }^{\mathrm{h}}$ & $75,201(90)$ & $37,029(90)$ \\
\hline
\end{tabular}

\section{Proportion of follow-up time after ART}


medRxiv preprint doi: https://doi.org/10.1101/2021.07.21.21260588; this version posted July 23, 2021. The copyright holder for this preprint (which was not certified by peer review) is the author/funder, who has granted medRxiv a license to display the preprint in perpetuity.

All rights reserved. No reuse allowed without permission.

\begin{tabular}{|c|c|c|}
\hline \multicolumn{3}{|l|}{ initiation } \\
\hline$<10 \%$ & $834(1)$ & $388(1)$ \\
\hline $10-24 \%$ & $895(1)$ & $382(1)$ \\
\hline $25-49 \%$ & $2,171(3)$ & $857(2)$ \\
\hline $50-74 \%$ & $4,108(5)$ & $1,868(5)$ \\
\hline $75-89 \%$ & $4,042(5)$ & $1,935(5)$ \\
\hline$\geq 90 \%$ & $63,528(75)$ & $31,806(78)$ \\
\hline Missing ART data & $8,315(10)$ & $3,739(9)$ \\
\hline Died & $14,345(17)$ & $4,062(10)$ \\
\hline Any incident cancer ${ }^{i}$ & $5,628(7)$ & $2,172(5)$ \\
\hline \multicolumn{3}{|l|}{ AIDS-defining cancers } \\
\hline Non-Hodgkin lymphoma & 497 & 251 \\
\hline Kaposi sarcoma & 501 & 253 \\
\hline Cervix & 47 & 41 \\
\hline \multicolumn{3}{|l|}{ HIV-associated cancers } \\
\hline Lung & 755 & 186 \\
\hline Anus & 439 & 209 \\
\hline Liver & 347 & 74 \\
\hline Hodgkin lymphoma & 176 & 84 \\
\hline Head and neck & 134 & 60 \\
\hline \multicolumn{3}{|l|}{ Other } \\
\hline Prostate & 817 & 163 \\
\hline Colorectum & 221 & 69 \\
\hline
\end{tabular}


medRxiv preprint doi: https://doi.org/10.1101/2021.07.21.21260588; this version posted July 23, 2021. The copyright holder for this preprint (which was not certified by peer review) is the author/funder, who has granted medRxiv a license to display the preprint in perpetuity.

All rights reserved. No reuse allowed without permission.

\section{Breast}

Other
79

1,615
61

721

IQR: interquartile range

${ }^{a}$ Ever documentation of alcohol abuse or at risk alcohol use. 2,165 (3\%) missing in primary analysis, $80(0 \%)$ missing in sensitivity analysis.

${ }^{b}$ Ever documentation of tobacco usage. 43,253 (52\%) missing in primary analysis, 5,660 (14\%) missing in sensitivity analysis.

${ }^{\mathrm{c}} \mathrm{CD} 4$ cell count at baseline (closest values within six months before or after). 13,170 (16\%) missing in primary analysis, 1,197 (3\%) missing in sensitivity analysis.

${ }^{\mathrm{d}} \mathrm{CD} 8$ and CD4/CD8 ratio at baseline (closest values within six months before or after). 15,915 (19\%) missing in primary analysis, 2,198 (5\%) missing in sensitivity analysis.

${ }^{\mathrm{e}} \mathrm{HIV}$ RNA at baseline (closest values with six months before or 30 days after). 12,772 (15\%) missing in primary analysis, $1,334(3 \%)$ missing in sensitivity analysis.

${ }^{\mathrm{f}}$ Body mass index at baseline (closest values within six months before or after). 21,989 (26\%) missing in primary analysis, 3,994 (10\%) missing in sensitivity analysis.

${ }^{\mathrm{g}}$ Geographic regions refers to location recorded closest to date of cohort entry. Other locations include Armed Forces Africa, Europe, Middle East, and Pacific and Guam.

${ }^{\mathrm{h}}$ Study exit includes earliest occurrence of first cancer, death, or administrative censoring. ART data missing for 8,315 (9.9\%) in primary analysis and 3,739 (9\%) in sensitivity analysis.

${ }^{\mathrm{i} A n y}$ incident cancer excludes non-melanoma skin cancers. 


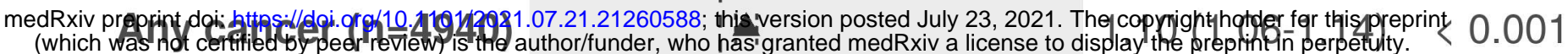

Non-Hodgkin lymphoma $(n=433)$

Kaposi Sarcoma $(n=401)$

Cervical $(n=43)$

Lung $(\mathrm{n}=664)$

Anal $(n=395)$

Liver $(\mathrm{n}=\mathbf{3 1 0})$

Hodgkin Lymphoma $(\mathrm{n}=157)$

Head and Neck $(n=120)$

Prostate $(n=724)$

Colorectal $(n=199)$

Breast $(n=65)$

:-A-: $\quad 1.53(1.31-1.79)<0.001$

$2.51(1.82-3.47)$

$1.35(1.12-1.64)<0.001$

$1.83(1.26-2.64)$

$1.03(0.69-1.54) \quad 0.912$

$1.09(0.58-2.06)$

$\div-1-:$
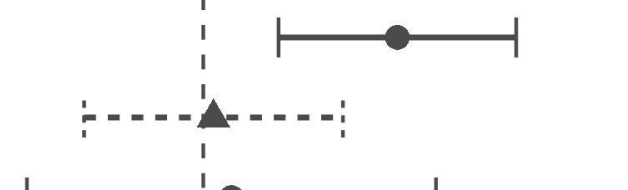

\section{F}
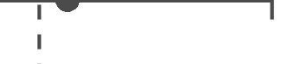

$-1-$

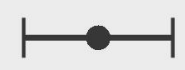

$-\mathbf{A - 1}$

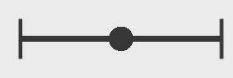

$\div-A_{1}^{\prime}-:$
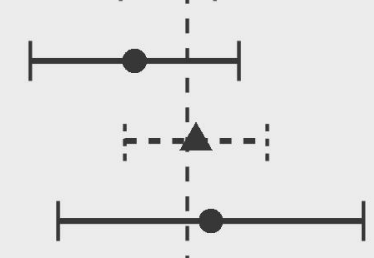

$-\frac{1}{1}-\Delta-=-i$

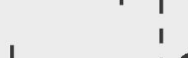

⺊

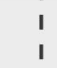

I

I

I

i'i:

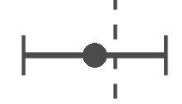

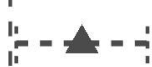

I

1

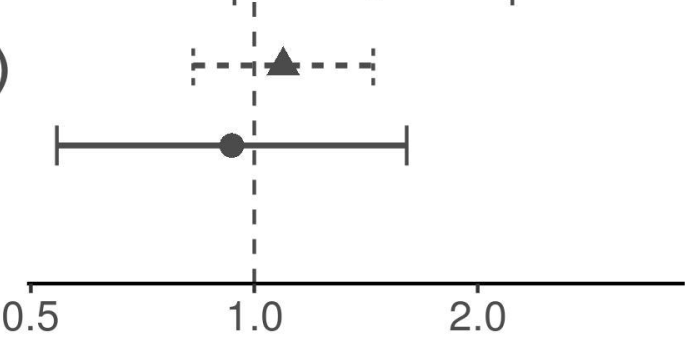

Adjusted Hazard Ratio $(95 \% \mathrm{Cl})$
$1.28(1.15-1.42)<0.001$

$1.66(1.32-2.10)$

$1.54(1.33-1.79)<0.001$

$2.33(1.71-3.18)$

$0.94(0.81-1.09) \quad 0.289$

$0.85(0.61-1.17)$

$1.03(0.82-1.28) \quad 0.877$

$1.08(0.67-1.73)$

$1.14(0.88-1.46) \quad 0.299$

$1.10(0.63-1.91)$

$0.96(0.87-1.06) \quad 0.839$

$0.94(0.75-1.17)$

$1.25(1.02-1.53) \quad 0.010$

$1.45(0.94-2.23)$

$1.09(0.83-1.45) \quad 0.353$

0.93 (0.54-1.60) 


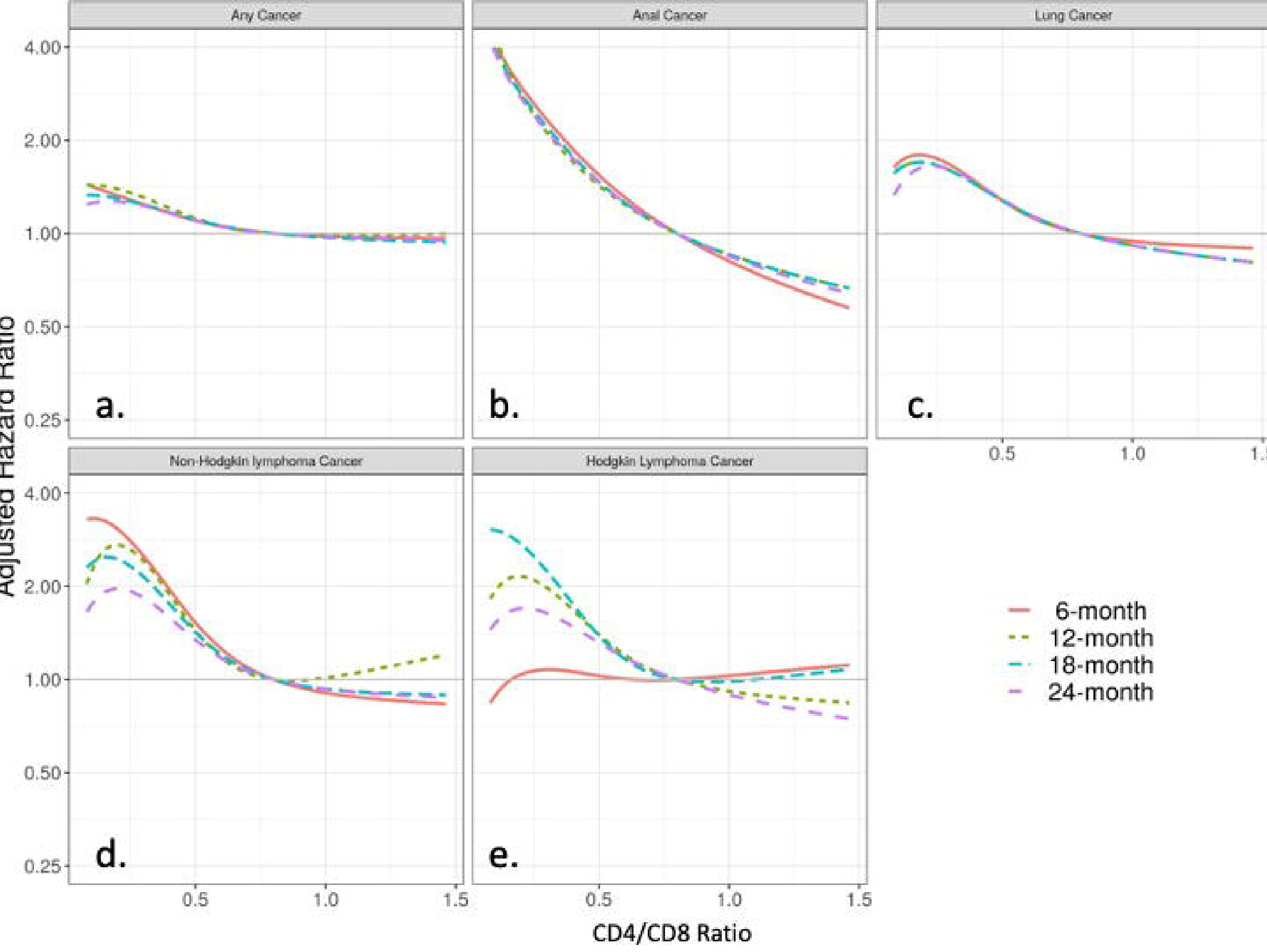




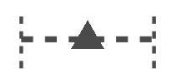

Kaposi Sarcoma $(n=211)$

$$
\begin{aligned}
& \text { Lung }(n=168) \\
& \text { Anal }(n=192)
\end{aligned}
$$

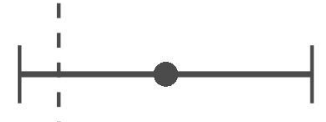

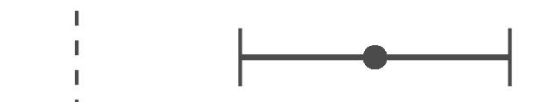$$
\text { :L- }
$$

3.11 (1.86- 5.19)

$1.21(0.92-1.61) \quad 0.318$

$1.50(0.86-2.62)$

0.318

$1.67(1.30-2.15) \quad<0.001$

$1.43(1.12-1.82) \quad 0.026$

$2.15(1.31-3.54)$

$1.47(1.16-1.86) \quad 0.002$

$2.00(1.22-3.26)$ 